\title{
PENGARUH KEBIJAKAN DIVIDEND, LIKUIDITAS DAN LEVERAGE TERHADAP NILAI PERUSAHAAN
}

\author{
Lely Syafawi \\ Universitas Islam Syekh Yusuf, Tangerang \\ Lelisya2178@gmail.com \\ https://doi.org/10.33.592/jeb.v25i2.426
}

\begin{abstract}
This study aims to determine the effect of the Dividend Policy (KD), Liquidity proxied by Current Ratio $(C R)$ and Quick Ratio $(Q R)$ and Leverage $(L G)$, partially and simultaneously to firm value $(P B V)$ at $L Q 45$ Company in Stock Exchange Indonesia period 2011-2015. Period used in this research is five years, starting from 2011-2015. The population in this study are companies incorporated in LQ 45 companies that have been and still listed in Indonesia Stock Exchange period 2011-2015. Samples were taken using Purposive Sampling method, from the population of 45 companies obtained 10 companies as a sample.Data were analyzed by using multiple linear regression. Based on the result of data analysis, it is concluded that partially the policy of Dividend, Current Ratio (CR), Quick Ratio $(Q R)$ and Leverage have no significant effect on company value. Based on the results of the $F$ test, simultaneous dividend policy (KD), Current Ratio (CR), Quick Ratio $(Q R)$ and Leverage (LG) against company value. This is indicated by the value of $F$ arithmetic of 1.259 and significance value 0.395. The value of determination coefficient (adjusted R2) of 0.103 indicates that the influence of dividend policy (KD), Current Ratio $(C R)$, Quick Ratio $(Q R)$ and Leverage ( $L G)$ to firm value is $10.3 \%$, and the rest is explained by other variables not examined in this study.
\end{abstract}

Keywords: Firm value, Dividend Policy, Current Ratio, Quick Ratio, Leverage

\begin{abstract}
Abstrak
Penelitian ini bertujuan untuk mengetahui pengaruh Kebijakan Dividend (KD), Likuiditas yang diproksikan oleh Current Ratio (CR) dan Quick Ratio (QR) dan Leverage (LG), secara parsial dan simultan terhadap nilai perusahaan (PBV) pada perusahaan LQ 45 di Bursa Efek Indonesia periode 20112015. Periode yang digunakan dalam penelitian ini adalah lima tahun yaitu mulai tahun 2011-2015. Populasi dalam penelitian ini adalah perusahaan-perusahaan yang tergabung dalam perusahaan LQ 45 yang sudah dan masih terdaftar di Bursa Efek Indonesia periode 2011-2015. Sampel diambil dengan menggunakan metode Purposive Sampling, dari populasi sebanyak 45 perusahaan diperoleh 10 perusahaan sebagai sampel. Data dianalisis dengan menggunakan regresi linier berganda. Berdasarkan hasil analisis data disimpulkan bahwa secara parsial Kebijakan Dividend, Current Ratio (CR), Quick Ratio (QR) dan Leverage berpengaruh tidak siginifikan terhadap nilai perusahaan. Berdasarkan hasil uji F, secara simultan kebijakan dividen (KD), Current Ratio (CR), Quick Ratio (QR) dan Leverage (LG) terhadap nilai perusahaan. Hal ini ditunjukkan oleh nilai $F$ hitung sebesar 1.259 dan nilai signifikansi 0,395. Nilai koefisien determinasi (adjusted R2) sebesar 0,103 menunjukkan bahwa pengaruh kebijakan dividen (KD), Current Ratio (CR), Quick Ratio (QR) dan Leverage (LG) terhadap nilai perusahaan sebesar $10,3 \%$, dan sisanya dijelaskan oleh variabel lain yang tidak diteliti dalam penelitian ini.
\end{abstract}

Kata kunci: Nilai perusahaan, Kebijakan Dividend, Current Ratio, Quick Ratio dan Leverage 


\section{A. Pendahuluan}

Kondisi perekonomian global saat ini telah menciptakan persaingan yang ketat antar perusahaan sehingga perusahaan terus berupaya untuk meningkatkan kinerja yang tercermin dalam nilai perusahaan. Nilai perusahaan menunjukan besarnya kemakmuran para pemegang saham sehingga selalu menjadi prioritas perusahaan (Meilani, 2014:1). Begitupun menurut Prastuti dan Sudiarta (2016:1573) yang mengatakan bahwa peningkatan harga saham akan berdampak pada nilai perusahaan yang akan memberikan kemakmuran bagi pemegang saham.

Firm value (nilai perusahaan) adalah salah satu indikator bagi pasar yang dapat memberikan penilaian secara menyeluruh terhadap suatu perusahaan (Salvatore 201:10). Indikator yang digunakan investor untuk memberikan nilai pada suatu perusahaan adalah pengukuran kinerja. Yang dijadikan indikator dalam menilai suatu nilai perusahaan adalah Price to Book Value (PBV) yang dianggap sebagai perbandingan harga pasar dari suatu saham dengan nilai bukunya. Perusahaan dikatakan berhasil apabila menciptakan nilai atau kemakmuran bagi pemegang sahamnya artinya nilai PBV semakin tinggi, begitupun sebaliknya (Nurminda, et.al 2017:543).

Kebijakan Dividend juga salah satu faktor yang dapat mempengaruhi nilai perusahaan. Artinya Kebijakan dividend adalah keputusan membayar atau laba yang dipertahankan untuk dapat di diinvestasikan kembali pada perusahaan (Sembiring et. al, 2010:48). Namun selain dividend, sebagian dana dibutuhkan untuk pengembangan perusahan, maka perlu dipertimbangkan.

Dividend menjadi suatu faktor utama bagi investor dalam menentukan dimana ia akan menanamkan investasinya. Para investor berharap dapat meningkatkan kesejahteraannya lewat pengembalian dividend, sedangkan perusahaan memiliki tujuan untuk terus mempertahankan keberlanjutan hidup perusahaan selain mensejahterakan pemegang saham (Wahyudi et.al, 2016:157). Dividend yang dibagikan dipresentasikan dalam bentuk Dividend Payaout Ratio (DPR).

Faktor selanjutnya yang dapat mempengaruhi nilai perusahaan adalah likuiditas. Likuiditas merupakan indikator mengenai kemampuan perusahaan untuk membayar semua kewajibannya. Apabila perusahaan tidak mampu dalam membayar kewajibannya, maka perusahaan tersebut akan memiliki pandangan yang negatif, dimana perusahaan berarti mengalami masalah keuangan. Hal ini dapat mengakibatkan kehilangan kepercayaan investor dan mempengaruhi tinggi rendahnya nilai perusahaan (putri, et.al 2016:3). Perusahaan dikatakan memiliki likuidasi yang baik jika kontribusi variabel likuiditas pada aspek current ratio (CR) dan Quick Ratio (QR) semakin besar presentasenya, sehingga persepsi terhadap kondisi perusahaan dirasa baik dan nilai perusahaan akan meningkat di mata investor (Nugroho, 2012:4)

Nilai perusahaan juga dapat di pengaruhi oleh Leverage tetapi tergantung pada besar kecilnya yang dihasilkan perusahaan. Leverage juga dapat dikatakan sebagai penaksir dari resiko yang seringkali dihadapi pada perusahaan. Artinya semakin besar Leverage dapat 
menunjukan resiko investasi yang semakin besar pula. Pengelolaan Leverage sangat penting karena pengunaan hutang yang tinggi akan meningkatkan nilai perusahaan (Novari \& Lestari, 2016:5673). Leverage dapat dijadikan ukuran dalam menilai kemampuan perusahaan guna memenuhi seluruh kewajiban finansialnya yang terdiri dari utang jangka panjang dan utang jangka pendeknya. Rasio Leverage dalam penelitian ini diwakili oleh DER (Debt to equity ratio) yang mana DER adalah perbandingan jumlah pinjaman jangka panjang yang diniliki perusahaan dengan jumlah sendiri. Artinya semakin besar DER maka akan semakin kecil laba yang akan dibagikan kepada pemegang saham, sehingga dapat menurunkan harga saham yang bersangkutan, dan sebaliknya (Sambora et al,2014:2). Menurut Novari \& Lestari (2016:5673), DER adalah rasio yang digunakan dalam pengukuran proporsi dana yang bersumber dari utang untuk membiayai aktiva perusahaan.

Dalam penelitian ini perusahaan yang dijadikan populasi adalah perusahaan LQ-45 yang terdaftar (listed) di Bursa Efek Indonesia periode 2011-2015. Dalam hal ini, perusahaan-perusahaan yang diteliti merupakan saham-saham emiten yang masuk dalam perhitungan indeks LQ45 yang aktif dan masuk dalam kategori blue chips yang diminati oleh investor dalam melakukan investasi saham di Bursa efek Indonesia. Dengan alasan itulah, maka penulis menjadikannya sebagai objek penelitian.

\section{Hipotesis}

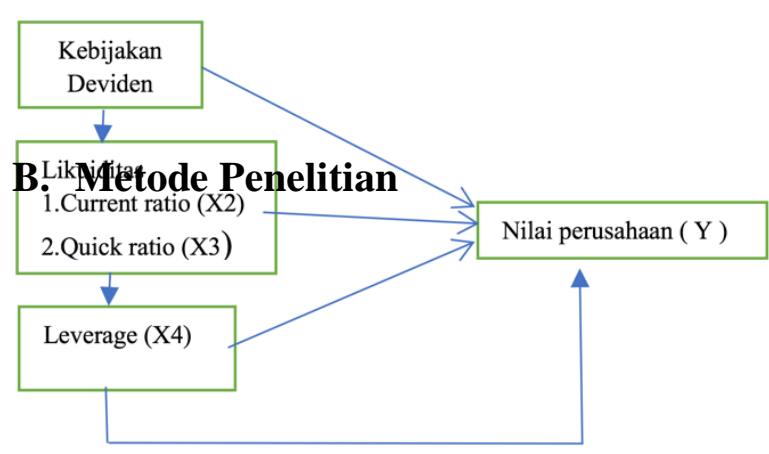

Dalam penelitian ini, objek yang dijadikan populasi adalah semua perusahaan yang terdaftar di LQ 45 yaitu sebanyak 45 perusahaan. Dari populasi tersebut kemudian akan dipilih untuk menjadi 10 sampel penelitian dengan menggunakan metode purposive sampling. Kriteria yang digunakan adalah sebagai berikut:

1. Mengeluarkan laporan tahunan secara rutin dalam periode 20112015.

2. Perusaahan LQ 45 yang terdaftar di Bursa Efek Indonesia.

3. Tidak bernilai negatif.

Hasil akhir, didapat 10 perusahaan yang memenuhi syarat-syarat yang telah ditetapkan. Analisis data pada penelitian ini menggunakan bantuan sofware computer program SPSS versi 22. Analisis ini bertujuan untuk menjawab hipotesis yang dianjurkan dalam penelitian ini. Teknik analisis data yang digunakan dalam penelitian ini adalah Regresi Linear Berganda. Adapun persamaan regresi digambarkan sebagai berikut:

$\mathrm{Y}=\mathrm{a}+\mathrm{b} 1 \mathrm{KD}+\mathrm{b} 2 \mathrm{CR}+\mathrm{b3} \mathrm{QR}+\mathrm{b} 4 \mathrm{LG}+\mathrm{e}$

Dimana dalam penelitian ini :

$\mathrm{Y}=$ Variabel nilai perusahaan

$\mathrm{a}=$ Intercept (Konstanta) yaitu nilai perkiraan jika $Y$ jika $X=0$

b1 $=$ Koefisien regresi untuk KD

b2 $=$ Koefisien regresi untuk CR

b3 = Koefiesien regresi untuk QR

b4 = Koefisien regresi untuk LG

$\mathrm{KD}=$ Variabel kebijakan deviden

$\mathrm{CR}=$ Variabel Current Ratio

$\mathrm{QR}=$ Variabel Quick Ratio 
$\mathrm{LG}=$ Variabel Leverage

\section{Hasil Penelitian dan Pembahasan}

Analisis regresi berganda digunakan untuk mengetahui pengaruh variabel bebas terhadap variabel tidak bebas (terikat) atas perubahan dari setiap peningkatan atau penurunan variabel bebas yang akan mempengaruhi variabel terikat. Hasil perhitungan regresi dengan menggunakan program SPSS 22 dapat dilihat pada tabel berikut ini:

\section{Tabel 1. Hasil Uji Regresi Linier Berganda}

\begin{tabular}{|c|c|c|c|c|c|c|}
\hline \multicolumn{7}{|c|}{ Coefficients ${ }^{\mathrm{a}}$} \\
\hline \multirow[b]{2}{*}{ Mode } & & \multicolumn{2}{|c|}{$\begin{array}{c}\text { Unstandardized } \\
\text { Coefficients }\end{array}$} & \multirow{2}{*}{$\begin{array}{c}\text { Standardized } \\
\text { Coefficients } \\
\text { Beta }\end{array}$} & \multirow[b]{2}{*}{ T } & \multirow[b]{2}{*}{ Sig. } \\
\hline & & B & Std. Error & & & \\
\hline 1 & (Constant) & $-3,387$ & 4,250 & &,- 797 & ,462 \\
\hline & Ln_KD & ,363 & 1,016 & 188 & ,357 & ,736 \\
\hline & $\mathrm{CR}$ & ,022 & , 015 & 2,177 & 1,476 & ,200 \\
\hline & Ln_QR & $-1,011$ & ,719 & $-1,195$ & $-1,405$ & ,219 \\
\hline & Ln_LG & 2,814 & 1,836 & 2,737 & 1,533 & , 186 \\
\hline
\end{tabular}

a. Dependent Variable: Ln_PBV

Dari hasil data Tabel 1 diperoleh hasil persamaan regresi linier berganda sebagai berikut:

$\mathrm{Y} \mathrm{i,t}=\alpha+\beta 1 \mathrm{X} 1 \mathrm{KD}+\beta 2 \mathrm{X} 2 \mathrm{CR}+\beta 3 \mathrm{X} 3$ $\mathrm{QR}+\beta 4 \mathrm{X} 4 \mathrm{LG}+\mathrm{e}$

$\mathrm{Y}=-3.387+0.363 \mathrm{KD}+0,22 \mathrm{CR}+-$ $1,011 \mathrm{QR}+2,814 \mathrm{LG}+\mathrm{e}$

Dari persamaan regresi diatas dapat diuraikan sebagai berikut:

Konstanta $=-3.387$ menunjukkan nilai negatif. Artinya variabel yang terdiri dari KD (Kebijakan Dividend), CR (Current Ratio), QR (Quick Ratio), dan LG (Leverage) $=0$, maka Price Book Value (Y) akan turun sebesar 3.387.

1. Koefisien b1 $=0.363$ menunjukkan angka positiff yang artinya bahwa setiap peningkatan KD (X1) 1 satuan dan (X) yang lain tetap, maka akan diikuti oleh peningkatan nilai perusahaan (Y) sebesar 0.363

2. Koefisien $\mathrm{b} 2=0,22$ menunjukkan angka positif yang artinya bahwa setiap peningkatan CR (X2) 1 satuan dan variabel $(\mathrm{X})$ yang lain tetap, maka akan diikuti oleh kenaikan Nilai perusahaan (Y) sebesar 0,243

3. Koefisien b3 $=-1,011$ menunjukkan angka negatif yang artinya bahwa setiap peningkatan QR (X3) 1 satuan dan variabel $(\mathrm{X})$ yang lain tetap, maka akan diikuti oleh penurunan Nilai perusahaan (Y) sebesar 1,011

4. Koefisien b4 $=2,814$ menunjukkan angka positif yang artinya bahwa setiap peningkatan LG (X4) 1 satuan dan variabel $(\mathrm{X})$ yang lain tetap, maka akan diikuti oleh peningkatan nilai perusahaan (Y) sebesar 2,814.

\section{Uji Hipotesa}

\section{a. Analisis Determinasi (R2)}

Hasil pengolahan data uji Koefisien korelasi dan koefisien determinasi sebagai berikut:

Tabel 2. Hasil Uji Koefisien Determinasi (R2)

\begin{tabular}{|l|c|r|r|c|}
\hline Model & $\mathrm{R}$ & R Square & $\begin{array}{c}\text { Adjusted R } \\
\text { Square }\end{array}$ & $\begin{array}{c}\text { Std. Error of the } \\
\text { Estimate }\end{array}$ \\
\hline 1 &, $708^{\mathrm{a}}$ &, 502 &, 103 & 1,01990 \\
\hline
\end{tabular}

a. Predictors: (Constant), Ln_LG, Ln_KD, Ln_QR, CR

\section{b. Uji parsial (Uji t)}

Uji- $\mathrm{t}$ digunakan untuk menguji koefisien regresi secara parsial atau individu dengan tingkat signifikan 0.05 $(\mathrm{a}=5 \%)$. Adapun hasil pengolahan data adalah sebagai berikut: 


\section{Tabel 3. Hasil Uji t}

\begin{tabular}{|c|c|c|c|c|c|}
\hline \multicolumn{6}{|c|}{ Coefficients ${ }^{\mathrm{a}}$} \\
\hline \multirow[b]{2}{*}{ Model } & \multicolumn{2}{|c|}{$\begin{array}{l}\text { Unstandardized } \\
\text { Coefficients }\end{array}$} & \multirow{2}{*}{\begin{tabular}{|c|}
$\begin{array}{c}\text { Standardized } \\
\text { Coefficients }\end{array}$ \\
Beta \\
\end{tabular}} & \multirow[b]{2}{*}{$\mathrm{t}$} & \multirow[b]{2}{*}{ Sig. } \\
\hline & B & Std. Error & & & \\
\hline 1 (Constant) & $-3,387$ & 4,250 & &,- 797 & .462 \\
\hline Ln_kP. H & dil L & $-\mathrm{t} \operatorname{tans} 6$ & H1 di,pers & lelbsal & igk,a36 \\
\hline & $\$ 7$ d927 & ana $\mathrm{t}-\mathrm{B}$ 月1 $\overline{\mathrm{p}}$ & ung lebih & ecit79: & Iri $t^{200}$ \\
\hline Ln_QR tal & $\$ 1-1,0(0)$ & $357<, 118$ & 12) -1 dब्ध & $\operatorname{gan} 405$ & nilaล่1؟ \\
\hline Ln_LG & ifikerth & si sebosa & or 0.7367 .3 & entws & kanst \\
\hline
\end{tabular}

a. Dependebalque: tniPaiv Signifikansi lebih besar dari 0.05 sehingga dapat dikatakan Kebijakan Dividend (X1) berpengaruh tidak signifikan terhadap Nilai Perusahaan (Y) secara parsial.

2. Hasil $\mathrm{Uji}-\mathrm{t}$ test $\mathrm{H} 2$ diperoleh angka 1.476 dimana t-hitung lebih kecil dari ttabel $(1.476<1.812)$ dengan nilai signifikansi sebesar 0.200. Menunjukan bahwa nilai Signifikansi lebih besar dari 0.05 sehingga dapat dikatakan Current Ratio (X2) berpengaruh tidak signifikan terhadap nilai perusahaan (Y) secara parsial.

3. Hasil Uji - $t$ test $\mathrm{H} 3$ diperoleh angka 1.405 dimana t-hitung lebih kecil dari ttabel $(1.405<1.812)$ dengan nilai signifikansi sebesar 0,219. Menunjukan bahwa nilai Signifikansi lebih besar dari 0.05 sehingga dapat dikatakan Quick Ratio (X3) berpengaruh tidak signifikan terhadap Nilai Perusahaan (Y) secara parsial.

4. Hasil Uji $-\mathrm{t}$ test $\mathrm{H} 4$ diperoleh angka 1.153 dimana t-hitung lebih kecil dari ttabel $(1.153<1.182) \quad$ dengan nilai signifikansi sebesar 0,186. Menunjukan bahwa nilai Signifikansi lebih besar dari 0.05 sehingga dapat dikatakan Leverage (X4) berpengaruh tidak signifikan terhadap Nilai Perusahaan (Y) secara parsial.

\section{c. Uji Simultan (Uji F)}

Uji $F$ digunakan untuk menguji pengaruh dari variabel $\mathrm{KD}, \mathrm{CR}, \mathrm{QR}$ dan LG terhadap nilai perusahaan, dapat dikatakan layak dengan tingkat signifikan $0,05(\mathrm{a}=5 \%)$. Berikut hasil pengolahan data terlihat pada tabel berikut:

Tabel 4. Hasil Uji F

\begin{tabular}{|c|c|c|c|c|c|c|}
\hline \multicolumn{7}{|c|}{ ANOVAa } \\
\hline \multicolumn{2}{|c|}{ Model } & $\begin{array}{l}\text { Sum of } \\
\text { Squares }\end{array}$ & Df & $\begin{array}{l}\text { Mean } \\
\text { Square }\end{array}$ & $\mathrm{F}$ & Sig. \\
\hline \multirow[t]{3}{*}{1} & Regression & 5,237 & 4 & 1,309 & 1,259 &, $395^{b}$ \\
\hline & Residual & 5,201 & 5 & & & \\
\hline & Total & 10,438 & 9 & & & \\
\hline
\end{tabular}

a. Dependent Variable: Ln_PBV

b. Predictors: (Constant), Ln_LG, Ln_KD, Ln_QR, CR

Kriteria :

Jika F hitung > F tabel, maka Ho ditolak dan Ha diterima.

Jika $\mathrm{F}$ hitung < F tabel, maka Ho diterima dan Ha ditolak. Atau,

Jika Sig < 0,05, maka Ho ditolak .

Jika Sig > 0,05, maka Ho diterima .

Dengan tingkat signifikan $5 \%$ dan derajat kebebasan df $1=4$ dan df $2=5$ maka tabel didapat $F(4 ; 5)=5,19$. Dalam perhitungan diperoleh nilai $\mathrm{F}$ hitung lebih kecil dari F tabel, yaitu 1,259 < 5,19 sehingga Ho diterima. Sedangkan jika dilihat dari nilai sig hitung adalah 0,395 yaitu > 0,05 maka keputusannya juga Ho diterima yang berarti hal ini menunjukkan bahwa secara simultan tidak terdapat pengaruh secara signifikan antara Kebijakan Dividend, Current Ratio, Quick Ratio dan Leverage terhadap nilai perusahaan LQ 45 yang terdaftar di Bursa Efek Indonesia (BEI) periode 2011-2015. 
Pembahasan Pengaruh Masing-Masing Variabel:

\section{Pengaruh Kebijakan Dividend (KD) terhadap Nilai Perusahaan}

Pada hipotesis pertama dikatakan bahwa pengaruh Kebijakan Dividend adalah positif terhadap Nilai Perusahaan. Hal ini tidak sesuai dengan pengujian yang menunjukan nilai signifikansi sebesar 0.736 artinya Kebijakan Dividend tidak signifikan pengaruhnya terhadap Nilai Perusahaan sehingga hipotesis ditolak. Hal ini sejalan dengan penelitian yang dilakukan oleh Norma Hidayah (2016:17) dalam penelitiannya dikatakan bahwa Kebijakan Dividend tidak berpengaruh terhadap Nilai Perusahaan sesuai dengan Dividend Irrelevance Theory yang dikemukakan oleh Miller dan Modligiani (1958) dalam Brigham (2001:66), menyatakan bahwa rasio pembayaran Dividend hanyalah rincian dan tidak mempengaruhi kesejahteraan para pemegang saham. Karena hal tersebut dianggap kebijakan Dividend tidak dapat mempengaruhi nilai perusahaan

\section{Pengaruh Likuiditas terhadap Nilai Perusahaan}

Dalam Penelitian ini Likuiditas diproksikan oleh Current ratio dan Quick Ratio. Hasil penelitian menunjukan nilai signifikansi sebesar 0.200 ini artinya bahwa Current Ratio berpengaruh tidak signifikan secara parsial terhadap nilai perusahaan dengan arah pengaruh yang positif. Hal tersebut mengindikasikan bahwa jika Current ratio mengalami kenaikan maka Nilai Perusahaan pun akan mengalami kenaikan.

Penelitian ini sejalan dengan penelitian yang dilakukan oleh Ramadhani Fhika (2016:43) dan Kasmir (2008:138) mengemukakan bahwa Quick Ratio dikatakan baik jika berada diatas rata-rata kalau rasio perusahaan di bawah rata-rata berarti perusahaan dianggap lebih buruk daripada perusahaan lain. Perusahaan harus menjual persediaaan yang dimiliki untuk menutupi hutang. Tetapi biasanya menjual persediaan dengan harga yang normal akan kesulitan, sehingga persediaan perusahaan harus dijual dibawah harga pasar,sehingga dengan sebab itu perusahaan akan mengalami kerugian.

\section{Pengaruh Leverage Terhadap Nilai Perusahaan}

Pada hipotesis pertama dikatakan bahwa Nilai Perusahaan dipengaruhi secara positif oleh Leverage. Hal ini tidak sejalan dengan pengujian yang menunjukan nilai signifikansi sebesar 0.186 artinya bahwa Leverage berpengaruh tidak signifikan terhadap Nilai Perusahaan sehingga dianggap hipotesis ditolak. Untuk membiayai aktivanya, perusahaan menggunakan dana yang dimiliki oleh perusahaan atau berasal dari modal sendiri sehingga perusahaan dapat mengurangi proporsi hutangnya. Oleh sebab itu perusahaan dapat meningkatkan nilai perusahaan karena rendahnya proporsi hutangnya dan sebaliknya.

\section{Pengaruh Kebijakan Dividend, Likuiditas dan Leverage terhadap Nilai Perusahaan}

Dari hasil penelitian secara simultan bahwa Kebijakan Dividend (KD), Likuiditas (CR \& QR) dan Leverage (LG) tidak berpengaruh secara signifikan terhadap Nilai Perusahaan dengan nilai signifikansi melebihi tingkat signifikansi $0.05(\mathrm{a}=5 \%)$ yaitu sebesar 0.395. Artinya 
banyak faktor-faktor lain yang dapat mempengaruhi Nilai Perusahaan diluar variabel-variabel yang diteliti.

Hasil koefisien determinasi adjusted R Square sebesar 0, 103 yang menunjukkan bahwa $10,3 \%$ nilai perusahaan di pengaruhi oleh variabel Kebijakan Dividend, Current Ratio, Quick Ratio dan Leverage, sisanya $89,7 \%$ nilai perusahaan di LQ 45 yang terdaftar di Bursa Efek Indonesia (BEI) periode 20112015 dipengaruhi oleh variabel lain yang diluar model regresi.

\section{Simpulan}

Berdasarkan hasil dan pembahasan yang telah diuraikan, maka dapat ditarik kesimpulan sebagai berikut:

1. Berdasarkan pengujian hipotesis secara parsial (uji-t) yang telah dianalisis, maka dapat di simpulkan sebagai berikut :

a. Secara parsial terdapat pengaruh tidak signifikan antara variabel Kebijakan Dividend (X1) terhadap nilai perusahaan(Y) LQ 45 yang terdaftar di Bursa Efek Indonesia tahun 2011-2015. Hal ini ditunjukan dengan nilai sig sebesar 0.735 , dimana nilai sig $>0.05$.

b. Secara parsial terdapat pengaruh tidak signifikan variabel Likuiditas yang dalam hal ini diproksikan oleh Current Ratio (CR) (X2) dan Quick Ratio (QR) (X3) terhadap nilai perusahaan LQ 45 yang terdaftar di Bursa Efek Indonesia tahun 20112015. Dimana nilai sig. Current Ratio yaitu sebesar 0.200, dimana nilai sig > 0.05. Sedangkan nilai Quick Ratio sebesar 0.219, dimana nilai sig $>0.05$. Tetapi Current ratio memiliki pengaruh positif Artinya jika CR naik maka nilai perusahaan pun ikut naik. Sedangkan Quick ratio memiliki pengaruh negatif artinya jika QR naik maka nilai perusahaan akan mengalami penurunan.

c. Secara parsial terdapat pengaruh tidak signifikan antara variabel Leverage (LG) (X3) Nilai Perusahaan LQ 45 (Y) yang terdaftar di Bursa Efek Indonesia tahun 20112015 dengan nilai sig sebesar 0.186. dimana nilai sig yang diperoleh > 0.05 .

2. Berdasarkan uji F (ANOVA) memperoleh hasil nilai signifikansi sebesar 0.395 dimana nilai signifikansi> 0.05 , sehingga dapat disimpulkan bahwa variabel Kebijakan Dividend, Current Ratio, Quick ratio dan Leverage secara simultan tidak dapat pengaruh terhadap nilai perusahaan LQ 45 yang terdaftar di Bursa efek Indonesia periode 2011-2015. 


\section{E. Daftar Pustaka}

Hidayah, Norma. (2016). Pengaruh Profitabilitas, Leverage, dan Kebijakan Dividend terhadap Nilai Perusahaan Food and Beverages. Jurnal Ilmu dan Riset Akuntansi (5), 9.

Meilani, W.P. (2014). Pengaruh Deviden Payout Ratio (DPR), debt equity ratio (DER), return aseet (ROA), dan Size Perusahaan terhadap Nilai Perusahaan pada Perusahaan Manufaktur yang terdaftar di Bursa Efek Indonesia. e-Journal. Tanjung Pinang; Univ. Maritim Raja Ali Haji

Novari, Mikhy \& Lestari, Vivi. (2016). Pengaruh Ukuran Perusahaan, Leverage, dan Profitabilitas Terhadap Nilai Perusahaan pada sektor Properti dan real Estate. EJurna Manajemen Unud (5),9.

Nugroho, A.W. (2012). Pengaruh Profitabilitas, Likuiditas dan Leverage Terhadap Nilai Perusahaan. Universitas Muhammdiyah Surakarta

Nurminda, et.al. (2017). Pengaruh Profitabilitas,Leverage dan Ukuran Perusahaan terhadap Nilai Perusahaan. E-Proceeding Management. Universitas Telkom

Ogolmagai, Natalia (2013). Leverage pengaruhnya terhadap Nilai Perusahaan pada Industri Manufaktur yang Go Public di Indonesia. Junal EMBA(1). 3. Universitas Sam Ratulangi, Manado.

Prastuti \& Sudiarta (2016). Pengaruh Struktur Modal, Kebijakn Dividend dan Ukuran Perusahaan terhadap Nilai Perusahaan pada Perusahaan Manufaktur.e-journal

Management.Universitas Udayana Bali

Priyatno, Duwi. (2008). Mandiri Belajar SPSS.Yogyakarta:Mediakom.

Putri et al, (2016) . Pengaruh Rasio Likuiditas dan Rasio Profitabilitas terhadap Nilai Perusahaan. Malang: Universitas Brawijaya

Salvatore, Dominick. (2011). Managerial Economics. Jakarta: Salemba Empat.

Sambora, et.al. (2014). Pengaruh leverage dan profitabilitas Terhadap Nilai Perusahaan. Jurnal Administrasi Bisnis (8),1. Februari.

Sembiring \& Pakpahan. (2010). Pengaruh Kebijakan Dividend Terhadap Nilai Perusahaan Pada Perusahaan Manufaktur Yang Terdaftar di Bursa Efek Indonesia. Bandung;Akuntansi Politeknik Negeri Bandung

Wahyudi, et.al .(2016). Pengaruh Ukuran Perusahaan, Profitabilitas, Kebijakan Dividend dan Keputusan Investasi terhadap Nilai Perusahaan. Jurnal Ilmu dan Riset Akuntansi.Univ. Muhammdiyah Surakarta.

Brigham, Eugene F. And Houston. (2001). "Manajemen Keuangan:, Edisi 8. Erlangga : Jakarta 